\title{
Pengaruh Pupuk Organik Cair Babadotan (Ageratum conyzoides) Terhadap Pertumbuhan Vegetatif Akar Hanjeli (Coix lacrima Jobi)
}

\author{
Effect of Liquid Organic Fertilizer (Ageratum conyzoides) on Root Vegetative Growth \\ of (Coix lacrima Jobi)
}

\author{
Author(s): Aditya Murtilaksono ${ }^{(1) *}$; Rika ${ }^{(1)}$ Hendrawan $^{(1}$ \\ (1) Universitas Borneo Tarakan \\ * Corresponding author: aditwalker02@gmail.com
}

\begin{abstract}
ABSTRAK
Tanaman hanjeli (Coix lacryma Jobi L) merupakan tanaman pangan serealia yang memiliki kandungan protein lebih tinggi jika dibandingkan dengan jagung dan padi, sehingga tanaman ini memiliki potensi sebagai makanan pangan alternatif. Pertumbuhan tanaman hanjeli tergantung pada pemberian pupuk dan penyerapan unsur hara oleh akar. Akar berperan penting dalam penyerapan unsur hara, akar yang sehat, proses fotosintensis akan optimal dan mendapatkan pertumbuhan tanaman hanjeli yang optimal. Penelitian ini bertujuan untuk mengetahui respon pertumbuhan vegetatif akar tanaman hanjeli menggunakan pupuk organik cair Ageratum conyzoides. Penelitian ini menggunakan Rancangan Acak Kelompok (RAK) 1 faktor yaitu dosis pupuk organik cair $A$. conyzoides yang berbeda. Perlakuan dalam penelitian ini yaitu P0 (kontrol), P1 (2.5 ml/tanaman), P2 (5 ml/tanaman), P3 (10 ml/tanaman), P4 (20 ml/tanaman), dan P5 (40 ml/tanaman) dengan masing-masing perlakuan diulang sebanyak 4 kali. parameter pengamatan yaitu jumlah akar, panjang akar terpanjang, volume akar, berat basah akar, berat basah pupus, berat kering akar, berat kering pupus, dan nisbah pupus akar. Data akan dianalisis menggunakan ANOVA apabila berbeda nyata akan dilanjut dengan uji lanjut DMRT. Hasil penelitian pada perlakuan P0 pada parameter jumlah akar tanaman hanjeli berbeda nyata terhadap perlakuan lainnya. Pemberian pupuk organik cair $A$. conyzoides memiliki pengaruh negatif terhadap pertumbuhan akar tanaman hanjeli yaitu menekan pertumbuhan akar, tetapi akar tanaman hanjeli masih dapat tumbuh pada pemberian dosis $40 \mathrm{ml} /$ tanaman pupuk organik cair.
\end{abstract}

\section{Kata Kunci:}

Ageratum conyzoides;

Akar;

Hanjeli;

Pupuk organik cair;

\section{Keywords:}

Ageratum conyzoides;

Hanjeli;

Liquid organic fertilizer;

Root;

\section{ABSTRACT}

Hanjeli is a cereal crop that has a higher protein content compared to corn and rice, so this plant has potential as an alternative food. The growth of hanjeli plants depends on the application of fertilizers and the absorption of nutrients by the roots. The root plays an important role in the absorption of nutrients, healthy roots, photosynthesis process will be optimal and get optimal growth of hanjeli plants. This study aims to determine the vegetative growth response of hanjeli plant roots using Ageratum conyzoides liquid organic fertilizer. This study used a randomized block design, namely the different doses of liquid organic fertilizer A. conyzoides. The treatments in this study were P0 (control), P1 (2.5 ml / plant), P2 (5 ml / plant), P3 (10 ml / plant), P4 (20 ml / plant), and P5 (40 $\mathrm{ml} /$ plant) with each treatment repeated 4 times. Observation parameters were root number, longest root length, root volume, root wet weight, dashed wet weight, root dry weight, dashed dry weight, and root drop ratio. Data will be analyzed using ANOVA if significantly different will be continued with Duncan's further test. The results of the study on the P0 treatment on the parameters of the number of roots of hanjeli plants were significantly different from other treatments. The application of A. conyzoides liquid organic fertilizer has a negative effect on the growth of hanjeli plant roots, which is to suppress root growth, but the roots of hanjeli plants can still grow at a dose of $40 \mathrm{ml}$ /plant liquid organic fertilizer. 


\section{PENDAHULUAN}

Tanaman pangan merupakan faktor penentu bagi kemajuan suatu Negara. Menurut CIA World FactBook pada Tahun 2017, Indonesia merupakan Negara dengan jumlah penduduk tertinggi keempat setelah China, India, dan Amerika Serikat. Semakin tinggi jumlah penduduk maka kebutuhan akan bahan pangan semakin tinggi. Tanaman pangan merupakan kebutuhan pokok manusia sebagai sumber energi karena mengandung karborhidrat (Wardan \& Kurniadi, 2015).

Tanaman hanjeli (Coix lacrima Jobi L) merupakan tanaman pangan serealia yang memiliki kandungan protein lebih tinggi jika dibandingkan dengan jagung dan padi, sehingga tanaman ini memiliki potensi sebagai pangan alternatif. Tanaman ini memiliki nilai gizi yang cukup tinggi. Menurut Grubben and Partohardjono (1996) biji hanjeli memiliki kandungan karbohidrat $(83 \%)$, protein $(10,50 \%)$ dan lemak (4,90\%). Apabila dibandingkan dengan padi, kandungan karbohidrat padi lebih tinggi dibandingkan dengan biji hanjeli namun kandungan protein dan lemak pada biji hanjeli lebih tinggi dibandingkan padi.

Menurut Viitso (2003) biji hanjeli mengandung lemak esensial yang terdiri atas $45,55 \%$ asam oleat dan $39 \%$ asam linoleat. Selain itu menurut penelitian Duke (1983) kandungan gizi biji hanjeli lokal per 100 gram mengandung 380 kalori, $12.2 \mathrm{~g}$ air, $154 \mathrm{~g}$ protein, $6.2 \mathrm{~g}$ lemak, 65.3 gram karbohidrat, 0.8 gram serat, $25 \mathrm{mg}$ kalsium, $435 \mathrm{mg}$ pospor, $5 \mathrm{mg}$ besi, $0.28 \mathrm{mg}$ Tiamin, $0.19 \mathrm{mg}$ riboflarin, $4.3 \mathrm{mg}$ Niasin.

Tanaman hanjeli mampu tumbuh pada tanah berpasir, lempung dan liat serta toleran terhadap tanah masam, netral dan basa. Kadar $\mathrm{pH}$ tanah yang optimal untuk pertumbuhan tanaman hanjeli yaitu 4,3-7,3 (Nurmala, 2011). Selain itu, pertumbuhan tanaman hanjeli juga tergantung pada pemberian pupuk dan penyerapan unsur hara oleh akar. Akar berperan penting dalam penyerapan unsur hara. Akar yang sehat dapat mengoptimalkan proses fotosintesis sehingga pertumbuhan hanjeli juga optimal (Ruminta, Yuwariah, \& Sabrina, 2017).

Penyerapan unsur hara melalui bulubulu akar yang terletak beberapa millimeter di belakang ujung akar (root tip). Akar tanaman merupakan organ penyerap unsur hara. Terdapat tiga peristiwa dalam proses penyerapan unsur hara yaitu aliran massa, peristiwa intersepsi akar dan peristiwa difusi. Laju penyerapan unsur hara ditentukan oleh tekanan akar dan laju transpirasi. Pengaruh transpirasi terhadap penyerapan dan translokasi hara ditentukan oleh umur tanaman, waktu, jenis hara dan konsentrasi larutan luar. Jenis hara dapat berpengaruh apabila peranan transpirasi lebih besar pada hara yang tidak bermuatan dibandingkan dengan ion (Wiraatmaja, 2017).

Jumlah unsur hara dalam tanah juga mempengaruhi proses penyerapan unsur hara. Salah satu cara untuk menyediakan unsur hara dalam tanah adalah dengan cara pemupukan. Pemupukan dapat dilakukan menggunakan pupuk organik (Haryadi, Yetti, \& Yoseva, 2015). Pupuk organik adalah pupuk yang berperan dalam meningkatkan aktivitas biologi, kimia, dan fisik tanah sehingga tanah menjadi subur dan baik untuk pertumbuhan tanaman (Indriani, 2011). Pupuk organik terbagi menjadi pupuk padat dan cair. Pupuk organik cair adalah larutan hasil pembusukan bahan organik yang berasal dari sisa tanaman, kotoran hewan maupun manusia dan memiliki kandungan lebih dari satu unsur hara (Pinus \& Marsono, 2011). Salah satu pupuk organik yang dapat digunakan adalah pupuk organik cair (POC) Babadotan (Ageratum conyzoidez). 
Babadotan mengandung senyawa alelopati yang dapat menghambat pertumbuhan tanaman lain tetapi tumbuhan ini juga memiliki kandungan unsur hara yang dapat digunakan dalam pertumbuhan tanaman (Aini, 2008). Babadotan mempunyai kandungan unsur hara seperti nitrogen, phosfor dan kalium. Unsur $\mathrm{N}$ berperan untuk merangsang pertumbuhan vegetatif tanaman, unsur $\mathrm{P}$ untuk mendorong pertumbuhan perakaran dan unsur K diperlukan untuk memperkuat tubuh tanaman. Hasil analisis kandungan daun Babadotan yang dilakukan di Laboratorium Ilmu Tanah Fakultas Pertanian Universitas Borneo Tarakan tahun 2017. Diperoleh kandungan N-total sebesar $0,17 \%$, kandungan $\mathrm{P}_{2} \mathrm{O}_{5}$ sebesar $31,660 \mathrm{mg} / 100 \mathrm{~g}$ dan $\mathrm{K}_{2} \mathrm{O}$ sebesar $22,715 \mathrm{mg} / 100 \mathrm{~g}$, dengan demikian adanya unsur hara $\mathrm{N}, \mathrm{P}, \mathrm{K}$ di dalam daun Babadotan dapat meningkatkan pertumbuhan tanaman. Menurut Untung (2011), babadotan memiliki kandungan $\mathrm{N}$ sebesar $6,3 \%$, $\mathrm{P}$ sebesar $0,5 \%$ dan $\mathrm{K}$ sebesar $4,7 \%$.

Berdasarkan penelitian Xuan et al., (2004) menyatakan bahwa pertumbuhan akar lobak menunjukkan hasil terbaik dengan pemberian ekstrak daun Babandotan sebanyak $5.0 \mathrm{gl}^{-1}$ dengan panjang akar lobak terbaik ukuran 12.5 mm. Diperkuat oleh Fitria (2011) tentang pengaruh gulma Cyperus Rotundus, Ageratum Conyzoides, dan Digitaria Adscendens terhadap pertumbuhan dan produksi tanaman tomat menyatakan bahwa terdapat interaksi antara jenis gulma dengan konsentrasi ekstrak terhadap panjang akar tanaman tomat. Penelitian ini menunjukkan bahwa babandotan lebih mempengaruhi panjang akar pada tanaman tomat dibandingkan dua gulma yang lainnya.

Hal ini menunjukkan bahwa tidak semua gulma adalah pengganggu pertumbuhan tanaman, terdapat jenis gulma tertentu yang dapat menjadi sumber unsur hara bagi tanaman. Berdasarkan hal tersebut, maka penelitian ini bertujuan untuk mengetahui respon pertumbuhan vegetatif akar tanaman hanjeli menggunakan POC babadotan.

\section{METODOLOGI}

Penelitian ini dilaksanakan pada bulan Januari - Mei 2018 di Lahan Fakultas Pertanian Universitas Borneo Tarakan. Alat yang digunakan yaitu cangkul, gogos sawit, parang, alat tulis, dan gelas ukur. Bahan yang digunakan yaitu benih hanjeli acc 37, air dan daun babandotan.

Penelitian ini menggunakan Rancangan Acak Kelompok satu faktor dengan 6 taraf perlakuan dan 4 kali ulangan. Taraf perlakuannya adalah: $\mathrm{P} 0=$ Kontrol; $\quad \mathrm{P} 1=2,5 \quad \mathrm{ml} \quad \mathrm{POC}$ Babandotan/Tanaman; $\mathrm{P} 2=5 \mathrm{ml} \quad \mathrm{POC}$ Babandotan/Tanaman; $\quad \mathrm{P} 3=10 \mathrm{ml} \quad \mathrm{POC}$ Babandotan/Tanaman; $\mathrm{P} 4=20 \mathrm{ml}$ POC Babandotan/Tanaman; P5=40 ml POC Babandotan/Tanaman. Sehingga didapatkan 24 satuan percobaan dengan luas lahan penelitian sebesar $159.5 \mathrm{~m}^{2}$

Pembersihan gulma di lahan penelitian merupakan tahap awal dari penelitian, kemudian mengukur luas dan dilanjutkan pengolahan lahan. Pengolahan lahan dilakukan satu minggu sebelum tanam, selanjutnya dibuat bedengan ukuran $2 \times 2 \mathrm{~m}$ dengan ketinggian bedengan 50 $\mathrm{cm}$. Jarak antar perlakuan sebesar $50 \mathrm{~cm}$ dan jarak antar ulangan sebesar $100 \mathrm{~cm}$, kemudian setiap lubang tanam diberikan pupuk dasar sebanyak 140 gram pupuk kandang. Benih yang digunakan adalah benih hanjeli acc 37 yang berasal dari Provinsi Jawa Barat. Sebelum penanaman, benih direndam dengan air selama 24 jam dan dipilih benih yang terbaik untuk ditanam.

Penanaman hanjeli dilakukan menggunakan sistem tugal dengan jarak tanam $40 \times 70 \mathrm{~cm}$ dan setiap bedengan terdapat 18 lubang tanam. Setiap lubang 
tanam diisikan 5 benih kemudian benih ditutup tanah dengan kedalaman tanam 3 $\mathrm{cm}$. Setelah tanaman berumur 2 minggu selanjutnya dilakukan penjarangan dan hanya satu tanaman per lubang tanam. Pemberian POC Babandotan dilakukan usia tanaman 3,5,7,9, dan 11 MST sesuai dengan perlakuan. Penyiraman dilakukan apabila tidak hujan sebanyak satu gelas air mineral per tananam setiap sore hari. Pencabutan gulma pada bedengan dilakukan umur 2,4,6, 8 dan 10 MST. Hanjeli yang berusia 12 MST di setiap bedengan dicabut untuk dilakukan pengamatan

Paramater yang diamati adalah jumlah akar, panjang akar terpanjang, volume akar, berat basah akar, berat basah pupus, berat kering akar, berat kering pupus dan nisbah pupus akar. Data yang telah diperoleh dari lahan penelitian selanjutnya dianalisis menggunakan Analisis Sidik Ragam (ANOVA) dengan taraf 95\% kemudian dilanjutkan dengan uji Duncan Multiple Range Test (DMRT) dengan taraf kepercayaan 5\% untuk mengetahui perbedaan antar perlakuan

\section{HASIL DAN PEMBAHASAN}

Berdasarkan Hasil analisis ragam dan uji lanjut DMRT diperoleh data untuk setiap parameter pengamatan yang disajikan pada Tabel 1 .

Tabel 1. Rata-Rata Respon Pertumbuhan Vegetatif Akar Tanaman Hanjeli Umur 3 Bulan Setelah Tanam

Table 1. The vegetative response of Hanjeli root growth at 3 months after planting

\begin{tabular}{ccccccccc}
\hline Perlakuan & \multicolumn{7}{c}{ Parameter Pengamatan } \\
\cline { 2 - 9 } & JA & PAT & VA & BBA & BBP & BKA & BKP & NPA \\
\hline Kontrol & $53,25 \mathrm{~b}$ & $74,98 \mathrm{a}$ & $128,75 \mathrm{a}$ & $101,29 \mathrm{a}$ & $411,25 \mathrm{a}$ & $23,27 \mathrm{a}$ & $152,50 \mathrm{a}$ & $6,44 \mathrm{a}$ \\
$\mathbf{2 , 5} \mathbf{~ m l}$ & $30,00 \mathrm{a}$ & $59,45 \mathrm{a}$ & $77,50 \mathrm{a}$ & $55,33 \mathrm{a}$ & $166,25 \mathrm{a}$ & $11,67 \mathrm{a}$ & $35,00 \mathrm{a}$ & $2,80 \mathrm{a}$ \\
$\mathbf{5} \mathbf{~ m l}$ & $44,00 \mathrm{ab}$ & $72,95 \mathrm{a}$ & $103,75 \mathrm{a}$ & $91,89 \mathrm{a}$ & $277,50 \mathrm{a}$ & $20,38 \mathrm{a}$ & $78,75 \mathrm{a}$ & $3,67 \mathrm{a}$ \\
$\mathbf{1 0} \mathbf{~ m l}$ & $26,25 \mathrm{a}$ & $70,38 \mathrm{a}$ & $100,00 \mathrm{a}$ & $77,11 \mathrm{a}$ & $151,25 \mathrm{a}$ & $13,98 \mathrm{a}$ & $50,00 \mathrm{a}$ & $3,38 \mathrm{a}$ \\
$\mathbf{2 0} \mathbf{~ m l}$ & $29,25 \mathrm{a}$ & $68,00 \mathrm{a}$ & $96,25 \mathrm{a}$ & $75,62 \mathrm{a}$ & $220,00 \mathrm{a}$ & $16,71 \mathrm{a}$ & $96,25 \mathrm{a}$ & $4,54 \mathrm{a}$ \\
$\mathbf{4 0} \mathbf{~ m l}$ & $35,00 \mathrm{a}$ & $62,18 \mathrm{a}$ & $70,00 \mathrm{a}$ & $55,97 \mathrm{a}$ & $216,25 \mathrm{a}$ & $11,86 \mathrm{a}$ & $45,00 \mathrm{a}$ & $3,51 \mathrm{a}$ \\
\hline
\end{tabular}

Keterangan : Angka-angka yang diikuti huruf yang sama dinyatakan tidak berbeda nyata dalam uji lanjut DMRT 5\%.. JA= Jumlah Akar (buah); PAT= Panjangan Akar Terpanjang (cm); VA= Volume Akar (ml); BBA= Berat Basah Akar (g); BBP= Berat Basah Pupus (g); BKA= Berat Kering Akar (g); BKP= Berat Kering Pupus (g); NPA= Nisbah Pupus Akar

Note $\quad$ : The numbers followed by the same letter are declared not significantly different in the DMRT $5 \%$ follow-up test. JA = Number of roots (fruit); PAT = Longest Root Length (cm); VA=Root Volume (ml); BBA = Root Wet Weight $(\mathrm{g}) ; B B P=$ Wet Weight $(\mathrm{g}) ; B K A=$ Root Dry Weight (g); $B K P=$ Dry Weight of Fertilized (g); NPA = Ratio Pupus Akar

Berdasarkan Tabel 1 diketahui bahwa dari seluruh perlakuan kontrol menunjukkan hasil tertinggi dibandingkan dengan perlakuan lainnya. Berdasarkan hasil uji lanjut DMRT diketahui bahwa kontrol tidak berbeda nyata terhadap pemberian POC babadotan $5 \mathrm{ml}$, tetapi berbeda nyata dengan perlakuan lainnya pada parameter jumlah akar, dimana rata- rata jumlah akar pada perlakuan kontrol sebesar 53,25 buah.

Jumlah akar berperan penting dalam proses penyerapan unsur hara. Menurut Sarief (1986) jika perakaran tanaman tumbuh dengan baik maka pertumbuhan bagian tanaman lainnya juga akan berkembang baik karena akar mampu menyerap unsur hara dan air yang dibutuhkan oleh tanaman. 


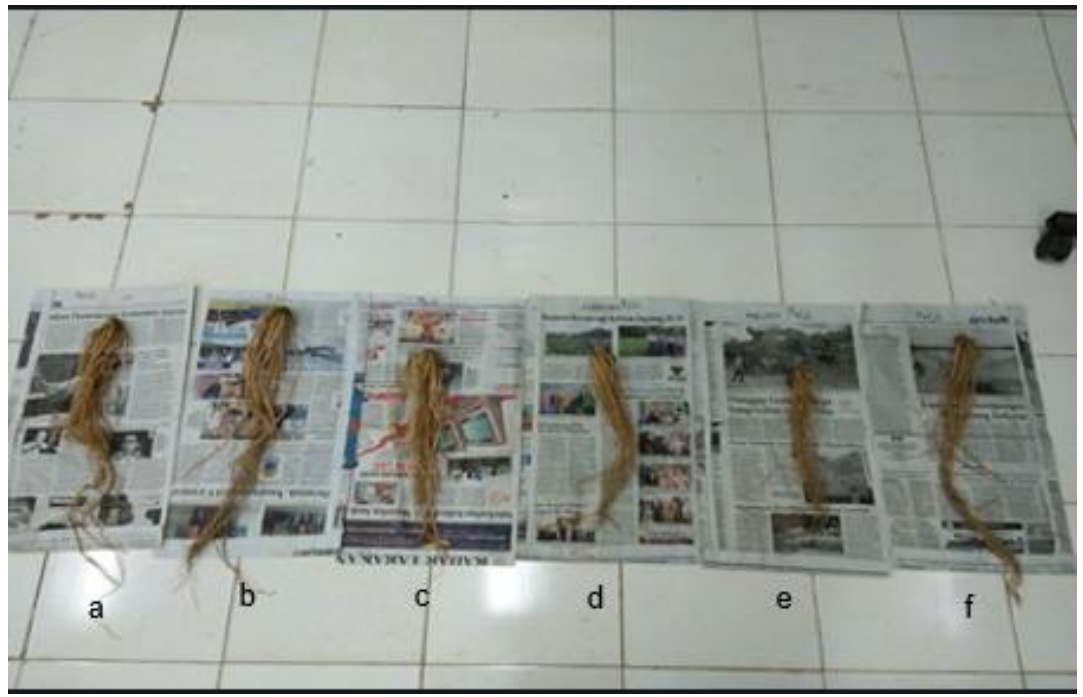

Gambar 1. Pertumbuhan akar hanjeli yang diberikan POC Babadotan umur 3 bulan (a) kontrol, (b) 2.5 $\mathrm{ml} / \tan$, (c) $5 \mathrm{ml} / \tan$, (d) $10 \mathrm{ml} / \mathrm{tan}$, (e) $20 \mathrm{ml} / \mathrm{tan}$, (f) $40 \mathrm{ml} / \mathrm{tan}$

Figure 1. Application of Babanotan Organic Liquid Fertilizer on the growth of Hanjeli roots at 3 monthsold-plant after planting, (a) Control, (b) $2.5 \mathrm{ml} /$ plant, (c) $5 \mathrm{ml} / \mathrm{plant,} \mathrm{(d)} 10 \mathrm{ml} / \mathrm{plant,} \mathrm{(e)} 20$ $\mathrm{ml} /$ plant, (f) $40 \mathrm{ml} /$ plant).

Gambar 1 menunjukkan bahwa perlakuan kontrol lebih baik dalam pertumbuhan akar tanaman hanjeli dibandingkan dengan perlakuan lainnya. Penambahan bahan organik ke dalam tanah diharapkan dapat membentuk struktur tanah yang gembur, sehingga memungkinkan air dan udara yang diperlukan untuk penyerapan unsur hara tersedia cukup dan seimbang. Sehingga perombakan bahan organik akan lancer yang berakibat pelepasan unsur hara $\mathrm{N}, \mathrm{P}$ dan $\mathrm{K}$ dalam tanah baik dan ketersediaan unsur hara meningkat (Sarief, 1986). Namun, dalam penelitian ini pemberian unsur hara berupa POC babadotan tidak memberikan perbedaan terhadap pertumbuhan akar tanaman hanjeli. Berdasarkan hasil tersebut, dapat diketahui bahwa pemberian POC Babandotan dapat menekan pertumbuhan akar hanjeli, dikarenakan babadotan mengandung alelopati di mana suatu senyawa yang dikeluarkan untuk menghambat pertumbuhan tanaman.
Tumbuhan babadotan sebagai alelopati diidentifikasikan karena adanya 3 phenolic acid yaitu gallic acid, comalid acid, dan protocatechuic acid Xuan et al., (2004) yang dapat menghambat pertumbuhan akar hanjeli. Penghambatan terhadap pertumbuhan akar hanjeli karena alelopati yang terkandung di dalam POC Babadotan, yaitu senyawa fenol dapat menghambat pertumbuhan hormon Indol asetat dan giberelin (Sastroutomo, 1990). Aktivitas giberelin berperan dalam merangsang pertumbuhan, apabila enzim tersebut terhambat maka pertumbuhan juga terhambat. Selain enzim pertumbuhan Indol asetat dan giberelin, senyawa feno juga menghambat hormon sitokinin. Menurut Pebriani et al., (2013) bahwa adanya senyawa alelokimia pada tumbuhan babadotan berupa fenol akan menghambat aktivitas sitokinin. Hambatan ini menyebabkan pembelahan sel sehingga pertumbuhan tanaman dapat terganggu.

Penghambatan pertumbuhan akar hanjeli yang mengakibatkan penurunan 
berat basah akar hanjeli. Hal ini terjadi karena alelopati yang terkandung dalam daun babadotan dapat mengakibatkan penurunan permeabilitas membran sel dan mengganggu kemampuan dalam penyerapan air serta unsur hara terlarut. Kerusakan struktur membran sel terjadi karena adanya senyawa alelokimia salah satunya fenol, karena fenol memiliki kemampuan yang dapat merusak fosfolipid sehingga mengakibatkan zat-zat penyusun sel serta metabolit keluar dari dalam sel (Triyono, 2009).

Pengaruh penyerapan unsur hara yang dilakukan oleh akar hanjeli dengan pemberian babadotan mengandung senyawa alelopati sehingga mengalami penurunan dalam jumlah akar, berat akar, panjang akar, berat basah maupun berat kering akan tetapi pemberian hingga dosis $40 \mathrm{ml}$ tanaman hanjeli masih dapat tumbuh dan berkembang.

\section{KESIMPULAN}

Berdasarkan hasil penelitian dapat disimpulkan bahwa pemberian POC babadotan tidak memberikan respon yang berbeda terhadap pertumbuhan vegetatif akar tanaman hanjeli, perlakuan terbaik pada setiap parameter pengamatan pada penelitian ini adalah .perlakuan kontrol, akan tetapi pemberian POC babadotan 40 $\mathrm{ml} /$ tanaman tanaman hanjeli masih dapat hidup dan tumbuh.

\section{DAFTAR PUSTAKA}

Aini, B. (2008). Pengaruh Ekstrak Alang琶 Alang (Imperata cylindrica), Bandotan (Ageratum conyzoides), dan Teki (Cyperus rotundus) Terhadap Perkecambahan Beberapa Varietas Kedelai (Glycine max L.) (Universitas Islam Negeri Maulana Malik Ibrahim Malang).

Duke, J. A. (1983). Handbook of Energy E Crops. Retrieved from https://www.cabdirect.org/cabdirect/ abstract/20177200306

Fitria, Y. (2011). Pengaruh Alelopati Gulma Cyperus Rotundus, Ageratum Conyzoides dan Digitaria Adscendens Terhadap Pertumbuhan dan Produksi Tanaman Tomat (Lycopersicon Esculentum Mill.) (Institut Pertanian Bogor).

Grubben, G. J. H., \& Partohardjono, S. EQ (1996). Plant resources of SouthEast Asia no. 10: cereals.

Haryadi, D., Yetti, H., \& Yoseva, S. (2015). Pengaruh Pemberian Beberapa Jenis Pupuk Terhadap Pertumbuhan dan Produksi Tanaman Kailan (Brassica alboglabra L.). Jurnal Online Mahasiswa Fakultas Pertanian, 2(2).

Indriani, Y. H. (2011). Membuat Kompos 县 Secara Kilat.

Nurmala, T. (2011). Potensi dan Prospek El Pengembangan Hanjeli (Coix lacryma jobi L) sebagai Pangan Bergizi Kaya Lemak untuk Mendukung Diversifikasi Pangan Menuju Ketahanan Pangan Mandiri. Jurnal Pangan, 20(1), 41-48.

Pebriani, Linda, R., \& Mukarlina. (2013). El Potensi Ekstrak Daun Sembung Rambat (Mikania Micrantha HBK) sebagai Bioherbisida terhadap Gulma Maman Ungu (Cleome rutidosperma DC) dan Rumput Bahia (Paspalum notatum Flugge). Jurnal Protobiont, 2(2), 32-38.

Pinus, L., \& Marsono. (2011). Petunjuk 副 Penggunaan Pupuk.

Ruminta, R., Yuwariah, Y., \& Sabrina, N. (2017). Respon Pertumbuhan dan Hasil Tanaman Hanjeli (Coix 
lacryma-jobi L.) terhadap Jarak Tanam dan Pupuk Pelengkap Cair. Agrikultura, 28(2), 82-89. https://doi.org/10.24198/agrikultura. v28i2.14958

Sarief, E. S. (1986). Kesuburan dan 县 Pemupukan Tanah Pertanian. Bandung: Pustaka Buana.

Sastroutomo, S. S. (1992). Pestisida: 尌 Dasar-dasar dan Dampak Penggunaannya.

Triyono, K. (2009). Pengaruh Saat 住 Pemberian Ekstrak Bayam Berduri (Amaranthus spinosus) dan Teki (Cyperus rotundus) terhadap Pertumbuhan dan Hasil Tanaman Tomat (Lycopersicum esculentum). Innofarm: Jurnal Inovasi Pertanian, 8(1), 20-27.

Viitso, T.-R. (2003). Phonology, 尌 morphology and word formation. In Estonian Language (Mati Erelt).

Wardan, R., \& Kurniadi, D. (2015). 钢 Aplikasi Multimedia Pembelajaran Rambu Lalu Lintas Berbasis Android. Jurnal Algoritma, 14(2), 125-132. https://doi.org/10.33364/ algoritma/v.14-2.125

Wiraatmaja, I. W. (2017). Zat Pengatur 尌 Tumbuh Auksin dan Cara Penggunaannya Dalam Bidang Pertanian (Universitas Udayana).

Xuan, T. D., Shinkichi, T., Hong, N. H., 顽 Khanh, T. D., \& Min, C. I. (2004). Assessment of Phytotoxic Action of Ageratum conyzoides L. (billy goat weed) on Weeds. Crop Protection, 23(10), 915-922. https://doi.org/ 10.1016/j.cropro.2004.02.005 